\title{
REKOMENDASI LATIHAN FISIK UNTUK DIABETES MELITUS TIPE 2
}

\author{
A Andi Kurniawan ${ }^{1}$, Y Nining Sri Wuryaningsih 2 \\ Indonesia Sports Medicine Centre \\ 2Fakultas Kedokteran Universitas Kristen Duta Wacana \\ Korespodensi : andi09ismc@gmail.com
}

\begin{abstract}
ABSTRAK
Diabetes melitus (DM) adalah kondisi penyakit kronik yang ditandai oleh metabolisme glukosa yang normsal sebagai dampak dari gangguan aksi dan sekresi insulin. Tatalaksana DM tipe 2 memelukan pendekatan multi disiplin, termasuk edukasi, terapi nutrisi, aktivitas fisik yag teratur, dan obat-obatan. Tujuan terapi DM tipe 2 adalah mencapai kadar gula yang normal dan mempertahankannya, serta mencegah komplikasi diabetes. Ada bukti ilmiah bahwa olahraga dapat menunda onset DM tipe 2 dan memperbaiki kontrol gula darah. Olahraga akan memperbaiki sensitivitas insulin, meningkatkan uptake glukosa, dan memperbaiki kontrol gula darah. Olahraga yang sifatnya aerobik akan menurunkan kadar HbA1C dan meningkatkan sensitivitas insulin. Kombinasi olahraga akan menabah perbaikan HbA1C.
\end{abstract}

Kata Kunci: Diabetes Melitus Tipe 2, Latihan aerobic dan ketahanan, Kontrol Glycemic, Sensitivitas Insulin. 


\title{
PHYSICAL EXERCISE RECOMMENDATIONS FOR TYPE 2 DIABETES MELITUS
}

\author{
A Andi Kurniawan ${ }^{1}$, Y Nining Sri Wuryaningsih 2 \\ Indonesia Sports Medicine Centre \\ 2Medical Faculty of Duta Wacana Christian University \\ Correspondence : andi09ismc@gmail.com
}

\begin{abstract}
Diebetes mellitus (DM) is a chronic disease characterised by abnormal glucose metabolism resulting from defects in insulin release, insulin action or both. The management of Type 2 DM requires a multifaceted approach, including educations, nutrition therapy, regular physical activity and exercise, and medications. The goal of treatment in Type $2 D M$ is to achieve and maintain optimal blood glucose and to prevent or delay chronic complications of diabetes. There is evidence to show that exercise can help prevent or delay the onset of T2DM, as well a improve blood sugar control. Acutely, exercise improves insulin sensitivity, facilitates glucose uptake and aids in glucose control. Aerobic exercise are well established, and interventions with more vigorous aerobic exercise programs resulted in greater reductions in $H b A(1 c)$, and greater increase in insulin sensitivity. Combined exercise training, aerobic exercise and resistance exercise seems to determine additional change in $H b A(1 c)$ that can be seen significant if compared with aerobic exercise alone and resistance exercise alone.
\end{abstract}

Keywords : Type 2 Diabetes Mellitus, Aerobic \& Resistance Exercise, Glycemic Control, Insulin Sensitivity. 


\section{PENDAHULUAN}

Diabetes Mellitus merupakan penyakit yang ditandai dengan gangguan metabolisme glukosa akibat gangguan pengeluaran insulin, kerja insulin atau keduanya. ${ }^{1}$ Diabetes adalah salah satu penyebab utama kematian di dunia. Penyebab kematian pada pasien diabetes berasal dari komplikasi dari penyakit yang berhubungan dengan diabetes, penyakit jantung merupakan penyebab yang paling menonjol. ${ }^{2}$

Secara garis besar diabetes dapat dikategorikan menjadi tipe 1 atau tipe 2. Dalam tipe 1, yang merupakan 5\% $-10 \%$ dari seluruh kasus diabetes, yang menjadi penyebabnya adalah kekurangan sekresi insulin secara absolut akibat kerusakan sel yang memproduksi insulin di pankreas oleh suatu proses autoimun. Diabetes tipe 2 (90\% $-95 \%$ dari seluruh kasus) merupakan kombinasi dari ketidakmampuan sel untuk merespon insulin (resistensi insulin) dan kompensasi sekresi insulin yang tidak memadai, sehingga menyebabkan kegagalan penyerapan glukosa ke dalam otot dan hati. ${ }^{2}$

\section{Diagnosis Diabetes Melitus Tipe 2}

American Diabetes Association
(ADA) pada tahun 2014 merekomendasikan untuk penegakan diagnosis diabetes melitus. ${ }^{2}$ Penetapan diagnosis berdasarkan setiap kriteria sesuai tabel berikut:

Tabel 1. Kriteria Diagnosis Diabetes Melitus

$\mathrm{A} 1 \mathrm{C} \geq 6.5 \%$. Tes A1C harus dilakukan pada laboratorium yang menggunakan metode NGSP yang tersertifikasi atau DCCT assay yang terstandar

Atau

Glukosa plasma puasa $\geq 126 \mathrm{mg} / \mathrm{dL}(7.0 \mathrm{mmol} / \mathrm{L})$. Puasa adalah tidak ada asupan kalori selama 8 jam

Atau

2 jam glukosa plasma $\geq 200 \mathrm{mg} / \mathrm{dL}(11.1 \mathrm{mmol} / \mathrm{L})$ dalam proses Tes Toleransi Oral Glukosa. Tes harus dilakukan sesuai standar WHO, yaitu menggunakan 75 g glukosa tidak terhidrasi yang dilarutkan dalam air

Atau

Individu dengan gejala klasik hiperglikemia (poliuri, polifagi dan penurunan berat badan tanpa diketahui penyebabnya) atau krisis hiperglikemia, glukosa plasma sewaktu $\geq 200 \mathrm{mg} / \mathrm{dL}(11.1 \mathrm{mmol} / \mathrm{L})$

Bila hasil tidak sesuai dengan keadaan hiperglikemia maka harus dilakukan konfirmasi dengan mengulangi tes untuk kriteria ketiga teratas.

\section{Tujuan Penatalaksanaan Diabetes Melitus Tipe 2}

Tujuan penatalaksanaan Diabetes Melitus Tipe 2 adalah untuk mencapai dan mengkontrol kadar gula darah optimal dan mencegah atau memperlampat komplikasi akibat DM tipe 2.2 Dalam konsensus Konsensus Pengelolaan dan Pencegahan DM tipe 2 di Indonesia 2011, penatalaksanaan dan pengelolaan DM dititik beratkan pada 4 pilar penatalaksanaan DM, yaitu: edukasi, terapi gizi medis, latihan fisik dan intervensi farmakologi. ${ }^{1}$ 


\section{Manfaat Latihan Fisik pada Penderita DM Tipe 2}

Beberapa bukti ilmiah telah menunjukkan bahwa latihan fisik dapat membantu mencegah dan memperlampat onset penyakit DM tipe 2 dan mengkontrol kadar gula darah.

Penelitian di Finlandia (Finnish Diabetes Prevention Study) menunjukkan bahwa kelompok intervensi dengan latihan fisik minimal 30 menit setiap hari dengan intensitas sedang terjadi penurunan $39 \%$ terhadap risiko terjadinya diabetes. ${ }^{3}$ Penelitian di Amerika Serikat (The US Diebetes Prevention Study) yang melibatkan 3234 subyek penelitian dengan intolerasi glukosa menunjukkan bahwa pada akhir penelitian kelompok dengan intervensi latihan fisik untuk menurunkan berat badan dan latihan fisik dengan intensitas sedang 150 menit seminggu dapat mengurangi risiko terjadinya diabetes $58 \%$ dibandingkan dengan kelompok yang mendapatkan intervensi obat metformin. ${ }^{4}$

\section{Efek Akut dan Kronis dari Aktivitas Fisik}

Efek segera atau akut dari latihan fisik pada DMT2 adalah meningkatkan sensitivitas insulin, memfasilitasi penyerapan glukosa dan membantu dalam mengontrol glukosa darah. Biasanya satu sesi latihan fisik akan dapat memberikan efek penurunan kadar glukosa darah hingga 72 jam pasca latihan.

Berikut beberapa bukti klinis terbaru yang direkomendasikan oleh ACSM mengenai efek akut dari latihan fisik pada DM tipe 2:5 (a)Dengan semakin meningkatnya intensitas aktivitas fisik, tubuh akan lebih banyak menggunakan karbohidrat sebagai bahan bakar kerja otot. Sehingga aktivitas fisik akan menyebabkan peningkatan penyerapan glukosa ke dalam otot yang bekerja yang akan diimbangi oleh produksi glukosa hepatik. (b)Penyerapan glukosa darah ke otot rangka yang dirangsang oleh kerja insulin, terutama terjadi saat istirahat dan mekanisme ini terganggu pada DMT2. Sementara itu, kontraksi otot merangsang penyerapan glukosa darah melalui mekanisme tambahan yang berbeda dan tidak terganggu oleh resistensi insulin atau DMT2. Karena keduanya merupakan dua jalur mekanisme yang berbeda, maka penyerapan glukosa darah ke dalam otot yang bekerja tetap berjalan normal bahkan ketika kerja insulin terganggu pada DMT2. Penyerapan glukosa darah ke dalam otot juga tetap meningkat setelah latihan karena mekanisme penyerapan glukosa darah yang dipengaruhi oleh kontraksi otot tersebut terus berlangsung selama beberapa jam. (a)Meskipun latihan aerobik intensitas sedang dapat memperbaiki kadar glukosa darah dan kerja insulin dengan segera, risiko terjadinya hipoglikemia akibat latihan fisik adalah minimal bila klien tidak menggunakan insulin ataupun obat golongan perangsang sekresi insulin. Hiperglikemia sesaat dapat terjadi setelah aktivitas fisik intensitas tinggi. (b)Efek akut dari latihan kekuatan otot atau latihan beban pada DMT2 belum dilaporkan, tetapi telah terbukti dapat menurunkan kadar gula darah puasa sedikitnya 24 jam setelah latihan pada individu dengan pra diabetes. (c)Kombinasi latihan aerobik dan latihan beban mungkin lebih efektif dalam meningkatkan kontrol glukosa darah. Namun, studi lebih lanjut diperlukan untuk menentukan apakah total pengeluaran kalori, durasi latihan, atau cara latihan fisik yang berpengaruh. ${ }^{5}$

Berikut beberapa bukti klinis terbaru yang direkomendasikan oleh ACSM mengenai efek kronis dari 
latihan fisik pada DM tipe 2: 5 (a) Latihan aerobik dan beban keduanya memperbaiki kerja insulin, pengendalian glukosa darah, dan oksidasi dan penimbunan lemak di otot. (b) Latihan beban akan meningkatkan massa otot rangka. (c) Studi observasional menunjukkan bahwa aktivitas fisik dan kebugaran yang lebih besar berhubungan dengan rendahnya angka kematian akibat komplikasi. (d) Tingkat aktivitas fisik yang direkomendasikan dapat membantu penurunan berat badan. Namun dibutuhkan latihan fisik hingga 60 menit per hari untuk menurunkan berat badan bila penurunan berat badan hanya mengandalkan latihan fisik semata. (e)Individu dengan DMT2 yang menjalani program latihan yang diawasi oleh tenaga terlatih menunjukkan tingkat kepatuhan yang lebih tinggi serta pengendalian kadar glukosa darah yang lebih baik dibandingkan mereka yang melakukan latihan olahraga tanpa pengawasan. (f)Peningkatan aktivitas fisik dan kebugaran fisik dapat mengurangi gejala depresi dan meningkatkan kualitas kesehatan penderita DMT2.

\section{LATIHAN FISIK PADA PENDERITA DM TIPE 2 DENGAN KADAR GLUKOSA DARAH NON-OPTIMAL}

\section{Hiperglikemia}

Pasien dengan DMT2 dan kadar glukosa darah yang meningkat (> 300 $\mathrm{mg} / \mathrm{dL}$ atau $16,7 \mathrm{mmol} / \mathrm{L}$ ) namun tanpa ketosis (keton dalam urin), dapat tetap menjalani program latihan, asalkan ia tidak merasakan keluhan apapun. Jika tidak dapat memastikan adanya ketosis, yang terbaik untuk dilakukan adalah menunda latihan sampai kadar glukosa darah terkendali. Hidrasi yang adekuat sangat diperlukan. Jika hiperglikemia terjadi setelah makan, individu dengan DMT2 masih akan mengalami penurunan kadar glukosa darah selama latihan aerobik karena tingkat insulin endogen (yang berasal dari dalam tubuh) kemungkinan masih akan meningkat pada saat itu. ${ }^{5}$

\section{Hipoglikemia: Penyebab dan Pencegahan}

Pada individu dimana diabetes hanya dikendalikan dengan pengaturan gaya hidup saja, risiko mengalami hipoglikemia $(<80 \mathrm{mg} / \mathrm{dL}$ atau 4,4 $\mathrm{mmol} / \mathrm{L}$ ) selama latihan sangatlah kecil. Pemantauan kadar glukosa darah dapat dilakukan sebelum dan setelah melakukan aktivitas fisik untuk menilai efek dari latihan. Aktivitas dengan durasi yang lebih lama dan intensitas yang lebih rendah umumnya akan menyebabkan penurunan kadar glukosa darah tapi hipoglikemia jarang terjadi.

$$
\text { Pada individu yang }
$$

menggunakan insulin atau obat perangsang produksi insulin, yang seringkali akan mengalami peningkatan penyerapan glukosa darah akibat latihan fisik dan insulin, aktivitas fisik dapat mempersulit penanganan diabetes. Bila kadar glukosa darah pra-latihan kurang dari $100 \mathrm{mg} / \mathrm{dL}$ (5.5mmol/L), maka dianjurkan agar pasien yang memakai insulin atau menggunakan obat perangsang produksi insulin (misalnya sulfonilurea seperti glyburide, glipizide, glimepiride serta nateglinide dan repaglinide) mengkonsumsi $15 \mathrm{~g}$ karbohidrat sebelum melakukan aktivitas fisik intensitas sedang. Jumlah karbohidrat tergantung pada durasi dan intensitas latihan serta hasil pemantauan kadar glukosa darah. Dokter kadang-kadang menginstruksikan pasien untuk mengurangi dosis obat / insulin sebelum melakukan program latihan intensitas berat dengan durasi $>1$ jam. 


\begin{abstract}
Hipoglikemia yang terjadi lambat (later-onset hypoglycemia) adalah sesuatu yang lebih mengkhawatirkan akibat simpanan karbohidrat (misalnya, glikogen otot dan hati) habis digunakan selama latihan fisik yang baru saja dilakukan. Pada pengguna insulin atau pengguna obat perangsang produksi insulin, latihan intensitas tinggi (misalnya latihan beban yang berat atau latihan interval berulang) terutama dapat mengakibatkan penurunan glikogen otot yang bermakna, sehingga meningkatkan risiko terjadinya hipoglikemia pasca latihan. Oleh karena itu, konsumsi 5-30 g karbohidrat dalam waktu 30 menit setelah melakukan latihan intensitas tinggi, akan menurunkan risiko terjadinya hipoglikemia dan membantu pemulihan glikogen otot yang lebih efisien. ${ }^{5}$
\end{abstract}

\section{Rekomendasi Latihan Aerobik pada DM Tipe 2}

Rekomendasi untuk latihan kardiovaskular pada DMT2 menggunakan prinsip FITT (Frequency Intensity Time Type). ${ }^{5}$

\section{Frekuensi}

Latihan aerobik dilakukan sedikitnya 3 hari dalam seminggu dengan jarak antar latihan tidak lebih dari 2 hari yang berturut-turut karena efek latihan yang bersifat sementara dalam memperbaiki kerja insulin. Rekomendasi sekarang bagi orang dewasa pada umumnya adalah 5 sesi latihan intensitas sedang dalam seminggu.

\section{Intensitas}

Latihan aerobik yang dilakukan sedikitnya intensitas sedang, yaitu sekitar 64-76 \% denyut jantung maksimal $\left(H R_{\max }\right)$. Bagi sebagian besar pasien DMT2, latihan fisik seperti jalan cepat, bersepeda dan renang, termasuk dalam latihan dengan intensitas sedang.

\section{Durasi}

Individu dengan DMT2 harus melakukan latihan aerobik minimal 150 menit per minggu dengan intensitas sedang atau berat. Aktivitas aerobik dapat dilakukan dalam sesi pendek dengan durasi sedikitnya 10 menit per sesi dan sesi ini dapat dilakukan sepanjang minggu. Latihan aerobik 150 menit per minggu dengan intensitas sedang berhubungan dengan menurunnya angka kesakitan dan angka kematian dalam penelitian observasional pada berbagai jenis populasi. Beberapa manfaat bagi sistem kardiovaskular dan kadar glukosa darah dapat dicapai dengan volume latihan yang lebih rendah (namun dosis minimal belum pernah ditetapkan), tapi dengan melakukan latihan dengan durasi melebihi anjuran minimal, lebih banyak manfaat akan diperoleh.

\section{Tipe}

Segala bentuk latihan aerobik (termasuk jalan cepat) yang menggunakan kelompok-kelompok otot besar dan menyebabkan peningkatan denyut jantung yang terus-menerus akan bermanfaat dan dianjurkan agar melakukan berbagai jenis aktivitas fisik.

Jadi, individu dengan DMT2 harus melakukan latihan aerobik sedikitnya 150 menit per minggu dengan intensitas sedang hingga berat selama minimal $3 \mathrm{x}$ seminggu dengan jarak antar latihan tidak lebih dari 2 hari berturut-turut.

\section{LATIHAN KEKUATAN OTOT ATAU BEBAN PADA DM TIPE 2. 5}

\section{Frekuensi}

Latihan beban harus dilakukan setidaknya dua kali seminggu pada 
hari yang tidak berturut-turut, tetapi lebih idealnya tiga kali seminggu, sebagai bagian dari program aktivitas fisik untuk individu dengan DMT2, bersamaan dengan latihan aerobik yang teratur.

\section{Intensitas}

Untuk memperoleh manfaat yang optimal dalam meningkatkan kekuatan dan kerja insulin, intensitas latihan yang dilakukan sebaiknya intensitas sedang $(50 \%$ dari 1 repetisi maksimal, atau 1-RM) atau berat (75$80 \%$ dari 1-RM). Latihan sendiri di rumah tanpa didampingi tenaga profesional mungkin kurang efektif untuk mempertahankan kontrol glukosa darah tapi cukup untuk menjaga massa dan kekuatan otot.

\section{Waktu}

Setiap sesi pelatihan setidaknya harus mencakup 5-10 latihan yang melibatkan kelompokkelompok otot utama (tubuh bagian atas, tubuh bagian bawah, dan core/ inti) dan melibatkan 10-15 repetisi per set di tahap awal pelatihan. Seiring waktu, berat beban dapat semakin bertambah sehingga hanya dapat diangkat sebanyak 8-10 kali. Untuk meningkatkan kekuatan otot secara optimal, dianjurkan untuk melakukan setidaknya satu set pengulangan hingga mendekati kelelahan, ataupun hingga 3-4 set.

\section{Tipe}

Latihan kekuatan
menggunakan esin dan beban
(misalnya dumbbells dan barbel)
dapat memberikan manfaat atau efek
yang cukup setara dalam hal
peningkatan kekuatan dan massa otot
yang ditargetkan. Beban yang lebih
berat mungkin diperlukan untuk
optimalisasi kerja insulin dan
pengendalian kadar glukosa darah.

\section{GABUNGAN LATIHAN AEROBIK DAN BEBAN 5}

Penggabungan kedua latihan olahraga aerobik dan resistensi dianjurkan. Kombinasi latihan yang dilakukan tiga kali seminggu pada individu dengan DMT2 akan memberikan manfaat yang lebih besar bagi pengendalian kadar glukosa darah dibandingkan dengan latihan aerobik atau resistensi saja.

Namun, hingga saat ini, berbagai penelitian menunjukkan bahwa total durasi latihan dan pengeluaran kalori yang paling besar dapat dicapai dengan mengkombinasikan latihan aerobik dan latihan beban, terutama bila keduanya dilakukan pada hari yang sama. Belum ada penelitian yang melaporkan bahwa latihan yang dilakukan setiap hari tapi berselangseling akan lebih efektif, atau mempelajari efek dari kombinasi latihan isokalori pada glukosa darah. Selain itu, tidak ada bukti yang nyata mengenai manfaat berbagai bentuk latihan yang lebih ringan, seperti yoga dan tai chi, dalam mengontrol kadar glukosa darah.

\section{Latihan Kelenturan 5,6}

Latihan kelenturan dapat dimasukkan sebagai bagian dari program latihan, namun bukan untuk menggantikan latihan yang lainnya. Kelompok individu usia lanjut juga disarankan untuk melakukan latihan yang mempertahankan atau meningkatkan keseimbangan, yang mungkin akan mencakup beberapa latihan kelenturan, dan hal ini penting terutama bagi individu dengan DMT2 yang berusia lebih tua dan lebih berisiko untuk jatuh. Latihan kelenturan perlu untuk dilakukan tapi bukan untuk menggantikan jenis latihan lain yang direkomendasikan. 


\section{Efek Obat pada Respons Latihan 5,6}

Untuk mencegah terjadinya hipoglikemia, individu dengan diabetes mungkin perlu mengurangi dosis obat-obat atau insulin yang dikonsumsi sebelum (dan mungkin setelah) latihan. Sangatlah penting untuk selalu mewaspadai timbulnya gejala dan tanda-tanda hipoglikemia ataupun peningkatan kadar glukosa darah (pra, selama dan pasca latihan). Pencatatan atau dokumentasi terjadinya berbagai hal tersebut merupakan informasi yang penting dalam membantu tenaga kesehatan menyesuaikan dosis pengobatan klien.

Klien penderita diabetes seringkali diberikan berbagai obat untuk kondisi atau penyakit penyerta, antara lain obat diuretik, beta blocker, inhibitor angiotensin-converting enzyme (ACE), aspirin, obat penurun kadar lemak dan lain-lain. Obat-obat ini umumnya tidak mempengaruhi respon latihan, dengan beberapa pengecualian: (a) Beta-blocker diketahui akan menumpulkan respon denyut jantung saat latihan dan menurunkan kapasitas latihan maksimal melalui efek inotropik dan kronotropik negatif. Mereka juga dapat menghalangi timbulnya gejala adrenergik dari hipoglikemia, sehingga meningkatkan risiko hipoglikemia yang tidak terdeteksi selama latihan. Namun, beta-blocker dapat meningkatkan kapasitas latihan pasien dengan penyakit kardiovaskular, dengan mengurangi iskemia koroner selama aktivitas. (b) Diuretik dapat menurunkan volume cairan dan darah secara keseluruhan yang mengakibatkan dehidrasi dan ketidakseimbangan elektrolit, terutama selama melakukan latihan di tempat yang panas. (c) Dosis tinggi golongan statin berhubungan dengan terjadinya myalgia (nyeri otot), terutama bila dikombinasikan dengan fibrat dan niasin.

\section{PERTIMBANGAN KHUSUS : LATIHAN DENGAN KOMPLIKASI JANGKA PANJANG DARI DIABETES 5,6}

\section{Penyakit Pembuluh Darah}

Untuk individu dengan penyakit pembuluh darah perifer dengan ataupun tanpa klaudikasio intermiten dan nyeri saat aktivitas fisik, berjalan santai hingga sedang, arm-crank, dan bersepeda semuanya untuk meningkatkan mobilitas, kapasitas fungsional, toleransi nyeri saat latihan dan kualitas hidup. Latihan kekuatan ekstremitas bawah juga akan meningkatkan kinerja fungsional yang diukur dengan kemampuan berjalan di treadmill, memanjat tangga dan berbagai parameter kualitas hidup.

\section{Neuropati Perifer}

Neuropati

perifer mempengaruhi ekstremitas, terutama tungkai bawah dan kaki. Hiperglikemia menyebabkan keracunan saraf sehingga terjadi kerusakan saraf dan apoptosis, yang menyebabkan kerusakan pembuluh darah mikro dan hilangnya perfusi (aliran darah). Gejala-gejalanya mucul sebagai rasa sakit dan/atau hilangnya sensasi, beserta aliran darah yang buruk, meningkatnya risiko mengalami cedera kaki, ulkus dan infeksi.

Latihan intensitas ringan sampai sedang dapat membantu mencegah timbulnya neuropati perifer. Klien tanpa ulkus akut pada kaki dapat melakukan latihan yang bersifat weight-bearing intensitas sedang, namun bila terdapat cedera, luka terbuka atau ulkus pada kaki, aktivitas fisik yang dilakukan harus dibatasi pada yang bersifat nonweight-bearing.

\section{Neuropati Otonom}




\begin{abstract}
Adanya neuropati otonom kardiovaskular/ cardiovascular autonomic neuropathy (CAN) meningkatkan risiko kematian dua kali lipat dan juga meningkatkan risiko terjadinya silent ischemia miokard, hipotensi ortostatik, atau takikardi saat istirahat. CAN juga akan menggangu toleransi latihan dan menurunkan denyut jantung maksimal.

Latihan aerobik intensitas sedang dapat meningkatkan fungsi otonom pada individu dengan ataupun tanpa CAN; Namun, perbaikan yang nyata mungkin hanya akan terlihat setelah latihan submaksimal akut. Pemeriksaan pendahuluan adanya CAN harus mencakup serangkaian tes otonom (termasuk variabilitas denyut jantung) yang akan mengevaluasi kedua cabang sistem saraf otonom.
\end{abstract}

\section{Retinopati}

Pada individu diabetes dengan retinopati proliferatif atau praproliferatif atau degenerasi makula, konsultasi ke dokter mata dianjurkan sebelum memulai program latihan intensitas tinggi. Berbagai aktivitas yang sangat meningkatkan tekanan intraokular (di dalam rongga mata) tidak disarankan untuk dilakukan oleh penderita penyakit proliferatif yang tidak terkontrol, karena adanya peningkatan risiko terjadinya perdarahan; seperti misalnya latihan aerobik atau latihan beban intensitas tinggi (yang menyebabkan peningkatan tekanan darah sistolik yang cukup besar), aktivitas yang menundukkan kepala ke bawah, dan latihan melompat.

Retinopati diabetik merupakan penyebab utama kebutaan di negaranegara berkembang dan berhubungan dengan peningkatan angka kematian kardiovaskular. Dengan melakukan latihan intensitas rendah sampai sedang, individu dengan retinopati dapat memperoleh beberapa manfaat, seperti misalnya peningkatan kapasitas kerja. Walaupun aktivitas fisik telah terbukti dapat mencegah berkembangnya degenerasi makula akibat usia, penelitian pada kelompok individu dengan DMT2 masih sangat sedikit.

Individu dengan retinopati proliferatif yang tidak terkendali harus menghindari aktivitas yang meningkatkan tekanan intraokular dan risiko perdarahan. Oleh karena itu, dianjurkan agar individu tersebut melakukan pengobatan sebelum memulai program latihan intensitas tinggi.

\section{Nefropati dan Mikro albuminuria}

Baik latihan aerobik maupun latihan kekuatan dapat meningkatkan fungsi fisik dan kualitas hidup individu dengan penyakit ginjal, walaupun peningkatan tekanan darah selama aktivitas fisik dapat menyebabkan peningkatan sementara kadar mikro albumin dalam urin. Nefropati diabetik terjadi pada sekitar $30 \%$ dari individu dengan diabetes dan merupakan faktor risiko utama kematian pada individu dengan diabetes. Mikro albuminuria merupakan hal yang sering terjadi dan menjadi salah satu faktor risiko terjadinya nefropati yang nyata dan kematian akibat masalah kardiovaskular. Pengendalian kadar glukosa darah dan tekanan darah yang ketat, beserta dengan olahraga dan perubahan pola makan dapat menghambat perburukan mikro albuminuria. Program latihan dapat menghambat perburukan nefropati diabetik pada manusia.

Latihan kekuatan otot sangat efektif dalam meningkatkan fungsi otot dan aktivitas sehari-hari yang biasanya sangat dipengaruhi oleh penyakit ginjal tahap lanjut. Sebelum memulai latihan, individu dengan nefropati yang nyata harus 
mendapatkan persetujuan dokter, dan melakukan stress testing untuk mendeteksi adanya penyakit jantung koroner dan respon denyut jantung serta tekanan darah yang abnormal.

Latihan harus dimulai pada volume dan intensitas rendah karena kapasitas aerobik dan fungsi otot berkurang secara nyata. Selain itu juga disarankan untuk menghindari manuver Valsava atau latihan intensitas tinggi untuk mencegah kenaikan tekanan darah yang berlebihan. Latihan aerobik intensitas sedang yang diawasi dan dilakukan selama sesi dialisis, sama efektifnya dengan latihan yang dilakukan di rumah, dan dapat meningkatkan kepatuhan pasien dalam melakukan latihan.

Latihan fisik dapat meningkatkan fungsi tubuh dan kualitas hidup pada individu dengan penyakit ginjal dan bahkan dapat dilakukan selama sesi dialisis. Adanya mikro albuminuria tidak berarti perlu dilakukan pembatasan latihan.

\section{Pertimbangan Khusus Lainnya}

Pemantauan glukosa darah sebelum dan setelah latihan adalah penting untuk dilakukan, terutama ketika hendak memulai atau mengubah program latihan.

Waktu pelaksanaan latihan bagi klien pengguna insulin atau obat hipoglikemik tertentu haruslah diperhatikan. Latihan tidak dianjurkan untuk dilakukan selama masa kerja insulin berada di puncak karena dapat menyebabkan terjadinya hipoglikemia. Latihan sebelum tidur juga tidak dianjurkan karena risiko adanya hipoglikemia pasca latihan yang tertunda. Namun, jika olahraga atau latihan pada larut malam perlu dilakukan, mungkin konsumsi karbohidrat perlu ditingkatkan.

Jangan menyuntikkan insulin ke dalam anggota tubuh yang dilatih.

\section{KESIMPULAN}

Latihan memainkan peranan penting dalam mencegah dan mengendalikan resistensi insulin, pra diabetes, DMT2, dan berbagai komplikasi akibat diabetes. Baik latihan aerobik maupun latihan kekuatan otot akan memperbaiki kerja insulin secara akut, serta dapat membantu pengendalian kadar gula dan lemak darah; tekanan darah; risiko penyakit kardiovaskular; angka kematian; dan kualitas hidup. Akan tetapi latihan harus dilakukan secara teratur dan mencakup berbagai jenis latihan agar dapat memberikan manfaat jangka panjang. Kebanyakan orang dengan DM tipe 2 dapat melakukan latihan dengan aman selama beberapa tindakan pencegahan tertentu dilakukan. Pemberian program latihan yang dapat meningkatkan aktivitas fisik secara keseluruhan sangatlah penting bagi individu dengan DM tipe 2 untuk mencapai kesehatan yang optimal.

\section{DAFTAR PUSTAKA}

1. Perkumpulan Endokrinologi Indonesia. Konsensus pengelolaan dan pencegahan diabetes melitus tipe 2 di Indonesia 2011. hlm.4-10, 15-29.

2. Standards of medical care in Diabetes 2014. Diabetes Care Volume 37, Supplement 1, Januari 2014.

3. Lindstrom J, Peltonen M, Eriksson $\mathrm{JG}$, et al. Improved lifestyle and decreased diabetes risk over 13 years : long-term follow-up ot the randomised Finnish Diabetes Prevention Study (DPS). Diabetologia. 2013;56(2):284-293.

4. Knowler WC, Barrett-Connor E, Fowler SE, Hamman RF, Lachin JM, Walker EA, Nathan DM. Reduction in the incidence of type 2 diabetes melitus with lifestyle intervention or metformin. New 
England Journal of Medicine. 2002;346(6):393-403.

5. Tan B, Chung-Sien Ng, Lim I. Exercise Prescription Guide. Exercise is Medicine Singapore. Changi General Hospital : Marshall Cavendish Editions, 2015.
6. Jonas S, Phillips EM. ACSM's exersice is medicine. A clinician's guide to exercise prescription. Philadelphia: Lippincott Williams \& Wilkins; 2008. 
